\title{
Sprawozdanie z konferencji pt. Przeszłość i perspektywy Instytutu Historii Uniwersytetu Eódzkiego, Eódź, 6-7 grudnia 2018 roku
}

K onferencja była pomyślana jako dwudniowe obrady podsumowujace obchody jubileuszu 70-lecia istnienia Instytutu Historii na Uniwersytecie Łódzkim (UŁ), przypadające na rok 2018. Referaty i dyskusje podzielone zostały na cztery sesje. Uroczyste otwarcie nastąpiło w czwartkowy poranek. Wzięli w nim udział prorektor ds. nauki UŁ, prof. Elżbieta Żądzińska, dziekan Wydziału Filozoficzno-Historycznego UŁ, prof. Maciej Kokoszko, a także dyrektor Instytutu Historii, prof. Dariusz Jeziorny.

Według koncepcji organizatorów w ciagu obu dni w każdej części troje mówców było zaproszonych z zewnatrz, a jeden reprezentował środowisko łódzkie. Pierwszy dzień miał charakter refleksji nad przeszłością. Taki też nadano mu tytuł: „Historia Instytutu Historii w oczach swoich i obcych". Przedpołudniowa część pierwszego dnia, prowadzona przez prof. Dariusza Jeziornego, składała się z czterech referatów. Występujący zajęli się kolejno ocena Instytutu Historii w różnych aspektach jego działalności. O Instytucie jako instytucji naukowej na tle innych ośrodków akademickich w Polsce mówił prof. Tadeusz Rutkowski z Uniwersytetu Warszawskiego. Dorobek historiograficzny środowiska łódzkiego przybliżył prof. Jan Pomorski z Uniwersytetu Marii Curie-Skłodowskiej w Lublinie. Próby współpracy między historykami a socjologami w latach pięćdziesiątych XX w. omówił profesor Marek Czyżewski $z$ Instytutu Socjologii UŁ. I wreszcie przybliżenia historii Instytutu na tle wydarzeń krajowych w okresie PRL podją się prof. Krzysztof Lesiakowski z Instytutu Historii UŁ. Była to naprawdę wartościowa ocena minionych 70 lat istnienia i działalności Instytutu, szczególnie ważna, gdyż dokonana przede wszystkim 
przez osoby spoza środowiska rodzimego. Nie była to niewatpliwie wyłącznie laurka grzecznościowa pod adresem organizatorów jubileuszu, choć miłych słów o tym, że dorobek łódzkich historyków jest zauważalny i ceniony w skali kraju, nie brakowało.

Popołudniowa część pierwszego dnia konferencji miała bardziej wspomnieniowy charakter. Czwórka profesorów-seniorów $z$ naszego środowiska wspominała swoją drogę do studiowania historii oraz własnej pracy od strony bardziej osobistej. Przy okazji opowiedziała o swoich mistrzach, o warunkach pracy naukowej w trudnych latach komunistycznych oraz o wydarzeniach zabawnych, dzięki czemu osoby dawno już wśród nas nieobecne uzyskały wyrazistość, a atmosfera funkcjonowania Instytutu Historii w minionych latach stała się bliższa. Swoimi przeżyciami z okresu pracy zgodzili się podzielić: prof. Wiesław Puś, prof. Alicja Szymczak, prof. Jan Szymczak i prof. Andrzej M. Brzeziński, a ich wypowiedzi moderował prof. Rafał Stobiecki. Niezwykle żywe w trakcie tego popołudnia były także reakcje $z$ sali, w tym gości $z$ zewnątrz, którzy studiowali w przeszłości w Instytucie Historii. Skorzystali na tym i dzisiejsi studenci, i młodsi pracownicy naukowi, niepamiętający $z$ autopsji lat sześćdziesiątych, siedemdziesiątych i osiemdziesiątych ubiegłego stulecia.

Drugi dzień konferencji koncentrował się na przyszłości. Ponownie podzielony był na dwie sesje - przedpołudniowa i popołudniowa. Jako że znani i uznani w Polsce specjaliści dzielili się swoją refleksja ekspercka nad perspektywami, to nie były to typowe referaty naukowe, ale dyskusja panelowa. Mówcy nie ograniczali się do przyszłości stojącej przed Instytutem Historii UŁ, ale raczej debatowali nad przyszłością historii jako dyscypliny akademickiej w Polsce, szczególnie że niedawno weszła w życie nowa ustawa o szkolnictwie wyższym, zwana „Konstytucja dla Nauki”. Dokument przygotowany pod kierunkiem ministra Jarosława Gowina może być dla historyków i w ogóle humanistów bardzo brzemienny w skutkach $z$ powodu bardzo nieprzyjaznych, a wręcz groźnych dla tych akurat dziedzin nauki rozwiązan prawnych i finansowych (określenie współczynników kosztochłonności, sposoby oceny dorobku naukowego zdecydowanie promujace nauki przyrodnicze i techniczne). W pierwszej części mieliśmy do czynienia $z$ refleksja nad przyszłością naukową historyków, moderowana przez prof. Sławomira M. Nowinowskiego. Profesorowie Tomasz Wiślicz z Instytutu Historii Polskiej Akademii Nauk w Warszawie, Krzysztof Zamorski 
z Instytutu Historii Uniwersytetu Jagiellońskiego w Krakowie, Rafał Wnuk $z$ Instytutu Historii Katolickiego Uniwersytetu Lubelskiego i Maciej Kokoszko $z$ UŁ omawiali zagrożenia stojące przed badaniami naukowymi. Wśród nich za największe uznano mieszanie się polityki do badań historycznych, trudności z umiędzynarodowieniem badań, brak stabilności w finansowaniu nauki, ciagłe zmiany $\mathrm{w}$ polityce awansów naukowych, forsowanie $\mathrm{w}$ tematyce badań wątków martyrologicznych $z$ dziejów naszego kraju oraz skupianie się na historii politycznej, przy zaniedbywaniu innych aspektów życia w przeszłości. Najgorzej w tym wypadku wyglądał, według większości zabierających głos mówców, dorobek historyków XX w., czyli historii najnowszej. Rozważano również szanse i wyzwania stojące przed badaniami naukowymi, możliwe jednakże do zrealizowania w szerszym zakresie po przezwyciężeniu wskazanych zagrożeń, mogących uderzyć w podstawy nauki historycznej.

Popołudniowy panel $z$ kolei, prowadzony przez prof. Annę Kowalską-Pietrzak, wicedyrektora Instytutu Historii UŁ, skupiał się na określeniu tego, jakich studiów historycznych potrzeba w dzisiejszej Polsce. I znów miał on charakter szerszy niż związany z Instytutem Historii. Czwórka uczestników: prof. Stanisław Roszak (Instytut Historii i Archiwistyki Uniwersytetu Mikołaja Kopernika w Toruniu), prof. Marek Białokur (Instytut Historii Uniwersytetu Opolskiego), prof. Maciej Fic (Instytut Historii Uniwersytetu Śląskiego) i dr Andrzej Kompa (prodziekan ds. jakości kształcenia na Wydziale Filozoficzno-Historycznym UŁ) była zgodna co do konieczności zmieniania sposobu nauczania $\mathrm{w}$ stronę proponowania form pozwalających studentom na współuczestnictwo w zajęciach zamiast metod podających. Wybrzmiały również wątki problemów $z$ biurokratyzacja procesu dydaktycznego w ostatnich latach, czego końca w najbliższej perspektywie raczej nie sposób się spodziewać. Zapis audio debat panelowych drugiego dnia będzie dostępny w całości na stronie internetowej Instytutu Historii UŁ.

Do dyskusji włączali się również uczestnicy konferencji spoza grona mówców, reprezentujących dużą część środowiska historycznego w naszym kraju. Po wygłaszanych referatach lub wypowiedziach $\mathrm{w}$ ramach panelów głos zabierali zarówno pracownicy naukowi, goście $z$ zewnątrz, jak i studenci naszego Instytutu, którzy licznie stawili się na obradach. Było to widoczne głównie pierwszego dnia konferencji, czyli tej dotyczącej przeszłości Instytutu Historii. Sprawy przyszłości interesowały studentów zdecydowanie 
mniej, jako że ani nie pracują naukowo, ani też nie nauczają historii na uniwersytecie. Można więc śmiało powiedzieć, że konferencja odegrała przy okazji spora rolę dydaktyczną w zaznajamianiu adeptów naszych kierunków studiów (historii i wojskoznawstwa) $z$ dziejami instytucji, w której pobierają naukę.

DARIUSZ JEZIORNY

UNIWERSYTET ŁÓDZKI*

(iD) https://orcid.org/0000-0002-3724-7213

${ }^{*}$ Wydział Filozoficzno-Historyczny, Instytut Historii, Katedra Historii Powszechnej Najnowszej, e-mail: dariusz.jeziorny@uni.lodz.pl. 